\title{
THE SAGA OF SOUTH AFRICAN POWS IN ANGOLA, 1975-82
}

\author{
Gary Baines \\ History Department, Rhodes University
}

\begin{abstract}
This article narrates the story of nine soldiers captured during and shortly after Operation Savannah, the codename for the South African Defence Force invasion of Angola in 1975-6. Eight of these soldiers were captured in Angola in three separate incidents by Angolan and/or Cuban forces, whereas the last was abducted from northern Namibia by SWAPO (the South West Africa Peoples' Organisation). The article then provides a chronological account of the sequels to this story that interweaves a number of threads: first, the account relates the South African government's attempts to suppress press coverage of these stories for fear of the political 'fall-out' that the matter might cause amongst the white electorate and in case it jeopardised secret negotiations to secure the release of the prisoners; and second, it uncovers the role played by intermediaries, especially the International Committee of the Red Cross (ICRC), in the sensitive and fraught negotiation process. It will be shown that the South African authorities adopted divergent approaches when dealing with SWAPO and the Angolans/Cubans to secure the release of prisoners of war (POWs). This is because the South African authorities regarded the former as involved in an internal insurrection whereas the latter were members of the military forces of sovereign states. Accordingly, they paid lip service to the Geneva Conventions in the case of Angolan and Cuban POWs but treated captured SWAPO cadres as 'terrorists' or 'criminals'.
\end{abstract}

\section{Introduction}

Military and diplomatic historians have paid scant attention to the stories of South African Defence Force (SADF) soldiers captured during the war waged in Namibia/Angola. ${ }^{1}$ Those captured during Operation Savannah (1975-6) warrant a

Scientia Militaria, South African Journal of Military Studies, Vol 40, $\mathrm{Nr} 2,2012$, pp. 102-141 doi: $10.5787 / 40-2-999$ passing mention in a few texts, ${ }^{2}$ and are alluded to in a recently produced documentary video series. ${ }^{3}$ Still, the details of their 29 months in captivity remain somewhat sketchy. We know little - if anything - of the conditions 
under which the prisoners were detained and little of how this episode shaped relations between the parties involved in the conflict in Angola. This ignorance owes much to the fact that Operation Savannah was conducted within a stifling security blanket which involved the suppression and manipulation of news by the South African authorities. ${ }^{4}$ The veil is only now being lifted. Hitherto secret information pertaining to the prisoners has become available in terms of the Promotion of Access to Information Act (No. 2 of 2000). Files archived in the Department of Defence's Documentation Centre, ${ }^{5}$ have been supplemented by declassified records of the Department of Foreign Affairs (DFA), as well as printed and other secondary sources. These records have enabled the author to construct a preliminary narrative of the saga of the South African POWs held captive in Angola between 1975 and 1978.

The story of the South Africans captured by the South West Africa People's Organisation (SWAPO) in Namibia in 1978 has recently been brought to the attention of the public. Johan van der Mescht is the subject of the short documentary film Captured. ${ }^{6}$ But the film has yawning gaps, not least of all the silence about the conditions of Van der Mescht's 51-month-long captivity. His portrayal as a victim challenges a viewpoint prevalent in some quarters that he had somehow betrayed his country by becoming a captive. More recently, the story of Van der Mescht and his meeting with his SWAPO captor has been related in the film Captor and Captive. ${ }^{7}$ The filmmakers seem to want to rehabilitate the reputation of Van der Mescht who was the victim of a smear campaign by the apartheid government to discredit him. Their project is also an exercise in reconciliation between erstwhile enemies. ${ }^{8}$ This essay has a rather more modest objective: to provide a context to understand something of the experiences of the POWs so that those who have previously chosen to remain silent might be comfortable to tell their stories, and to repudiate any sense of shame with which they might be burdened as a result of their memories of captivity.

The author has chosen to call these captives prisoners of war (POWs) or krygsgevangenes. But this designation was not necessarily accepted by all parties involved in the conflict in Angola/Namibia. Because the conflict combined the characteristics of an (anti-)colonial, (counter-)insurgency and conventional war, the question of who qualified as a combatant, and hence a POW, was bound to be a contentious issue. The definitions of the status of combatants and POWs are not determined solely by the law of armed conflict (LOAC). The Geneva Conventions 
were designed for traditional armed conflicts between states and their uniformed military forces. Combatants who participated in irregular warfare were effectively excluded from the purview of the Conventions until the signing of the 1977 Additional Protocol. Under Article 43 of this Protocol, the armed forces of a national liberation movement were to be accorded POW status in the event of capture, provided they operated under some structure of command and were subject to a system of internal military discipline. Article 44 stipulates that combatants had to carry arms openly and wear some sort of uniform to distinguish them from the ordinary civilian population if only during actual military engagement. ${ }^{9}$

More often than not, combatants captured during the war in Namibia/Angola were discreetly executed following their interrogation. ${ }^{10}$ However, when it suited South Africa's purposes, it was prepared to recognise the Peoples' Armed Forces for the Liberation of Angola (FAPLA) and Cuban armed personnel as combatants and treat those captured as POWs. But South Africa declined to sign the 1977 Protocol or agree to any measures that might have accorded SWAPO's armed struggle legitimacy. It treated the insurgency as a domestic law and order issue rather than as a matter of international law. ${ }^{11}$ Thus, the South African authorities who occupied Namibia obstinately refused to treat cadres of SWAPO's armed wing, the Peoples' Liberation Army of Namibia (PLAN), as anything other than common criminals and 'terrorists'. SWAPO, on the other hand, stated a willingness to observe the Protocol and to treat captured SADF soldiers as POWs. ${ }^{12}$ This gesture, along with SWAPOs recognition by the UN General Assembly as "the sole authentic representative of the Namibian people", ${ }^{13}$ bolstered SWAPO's own claim to be the government-inwaiting of the Namibian proto-state.

This article relates the stories of South Africa's nine POWs captured in the Namibian/Angolan conflict during the period 1975-78. It will argue that the apartheid regime's anti-communist rhetoric was largely for the consumption of the white electorate and that realpolitik demanded a good deal of pragmatism in dealing with South Africa's enemies so as to secure the release of POWs. It will show that the South Africans adopted a multi-track strategy in their dealings with their adversaries. From 1976 the South Africans held a series of bilateral meetings with the Angolans about matters relating to the Angolan conflict, and the POW issue was included on the agenda. ${ }^{14}$ South African diplomats also approached the Angolans/Cubans via intermediaries - the International Committee of the Red Cross (ICRC) as well as other parties. The ICRC's relatively secretive behind-the-scenes 
manoeuvres were hidden from public scrutiny at the time and have largely remained so ever since. ${ }^{15}$ However, the roles of the key players on the South African side can now be revealed. For instance, it can be shown that the Ministries of Defence and Foreign Affairs worked in tandem - but often at cross-purposes - to secure the release of the POWs. And it can also be shown that the turf war conducted by the shadowy intelligence services, such as the Military Intelligence Division (MID) and the Bureau for State Security (BOSS), complicated the dynamics of the diplomacy. Personnel from both these agencies frequently operated outside the law and of the chain of command that existed within the Ministries of Defence and Foreign Affairs. ${ }^{16}$ Their lack of accountability rendered them both assets and liabilities in the politically sensitive negotiations for the exchange of POWs. But their bit roles were tangential to the process.

\section{Operation Savannah's sequels}

In October 1975, the SADF launched a covert operation aimed at preventing the People's Movement for the Liberation of Angola (MPLA) from assuming sole control of the former Portuguese colony. The SADF personnel were supposed to be volunteers - at least, that was the instruction given by the Minister of Defence. But national servicemen were actually obliged to join the task force and were made to sign a declaration that they had agreed to remain incognito and not to disclose any details about the nature of the operation in which they were involved. In so doing, the SADF troops effectively forfeited the right to be treated in terms of the Geneva Conventions that governed the LOAC. South African soldiers swapped their SADF uniforms for Portuguese camouflage dress or nondescript green kit so as to masquerade as mercenaries. They were ordered not to carry any form of identification, including dog tags. And they were instructed to speak English and create the impression that they were from Britain - a tall order for those with pronounced Afrikaans accents. South Africa suffered acute political embarrassment when the international media exposed the role of the SADF in the fighting. Despite the failure to keep the SADF's invasion of Angola secret, Defence Minister PW Botha only announced to the South African public that their sons were in Angola after the Cabinet had already taken the decision to withdraw. ${ }^{17}$

Whilst the SADF claimed successes on the battlefield, Savannah was an ad hoc operation without clear-cut strategic objectives. It proved to be a political miscalculation of monumental proportions. Instead of consolidating the position of Holden Roberto's FNLA in the north and Jonas Savimbi's UNITA in the south of 
the country, respectively, the South African invasion provided the newly installed MPLA government in Luanda with reason to increase the deployment of Cuban troops and Soviet advisors exponentially. ${ }^{18}$ South Africa's military adventurism was widely condemned in international forums and only added to the pariah state's isolation. Its faith in the USA proved misplaced. The Central Intelligence Agency (CIA) delivered limited assistance from secret funds, but Kissinger's promise of diplomatic support proved chimerical. And the Vorster government's 'outwardlooking' policy in Africa had to be scuttled. There was also some domestic political 'fall out' from Operation Savannah. This resulted as much from the National Party government's inept public relations as from its failure to agree upon and achieve strategic military objectives. The public were kept in the dark about the incursion for fear of alarming the parents of the national servicemen who were deployed on foreign soil in terms of the 1957 Defence Act. ${ }^{19}$ Moreover, more than 30 SADF personnel were killed and seven captured. ${ }^{20}$

While Botha claimed that South African intervention in Angola was confined to securing the border and the Cunene hydroelectric scheme, four SADF soldiers were captured deep within that country. ${ }^{21}$ This occurred on 13 December 1975 shortly after the Battle of Bridge 14 on the Nhia River (Cuanza Sul) near Catofe. ${ }^{22}$ Three days later, the South Africans were displayed to the media in Luanda in order to expose the SADF's involvement in the Angolan civil war. They were identified as:

- Cpl Johannes Gerhardus Terblanche

- Pvt Robert Wilson

- Pvt Graham Danney

- Pvt Robert Wiehahn.

These were not frontline troops; they were attached to the Technical Services Corps that was part of the mechanical support team accompanying Battle Group Foxbat. Terblanche was a permanent force member, while the other three were national servicemen. ${ }^{23}$ A Defence Headquarters statement claimed that the soldiers were captured while recovering an unserviceable vehicle in the operational area'. In fact, they had been captured $20 \mathrm{~km}$ north of the bridge over the Ntua River on the road to Quibala - a distance of some $750 \mathrm{~km}$ north of the Namibian/Angolan border. $^{24}$

On 17 December 1975, Danney and Wiehahn were interviewed on Radio Luanda. Under cross-examination by a Commander Juju, they feigned varying 
degrees of ignorance about the objectives of the operation in which they were involved. They claimed that details of the combat mission were not revealed to them and that they had only operated in a support capacity. They informed their questioner that their kit had been issued to them at Grootfontein on 24 November 1975 , prior to them setting out on a northward advance that had taken them via $\mathrm{Sa}$ da Bandeira to Cela. They were apparently instructed that, if they should become involved in contact with Angolan forces, they would be able to distinguish between MPLA who wore hats with insignia and FNLA/UNITA who did not. They admitted that they were not wearing regular SADF uniforms when they were captured. ${ }^{25}$ This admission amounted to a propaganda coup for the MPLA. The POWs were living proof of a South African invasion and provided ample justification for the MPLA government's invitation to Cuba to reinforce its defences against unprovoked SADF aggression. But it was the visual imagery that did the most damage to the apartheid state. A photograph of the four dejected young white South Africans was given worldwide exposure. Their body language suggests shame, even disgrace.

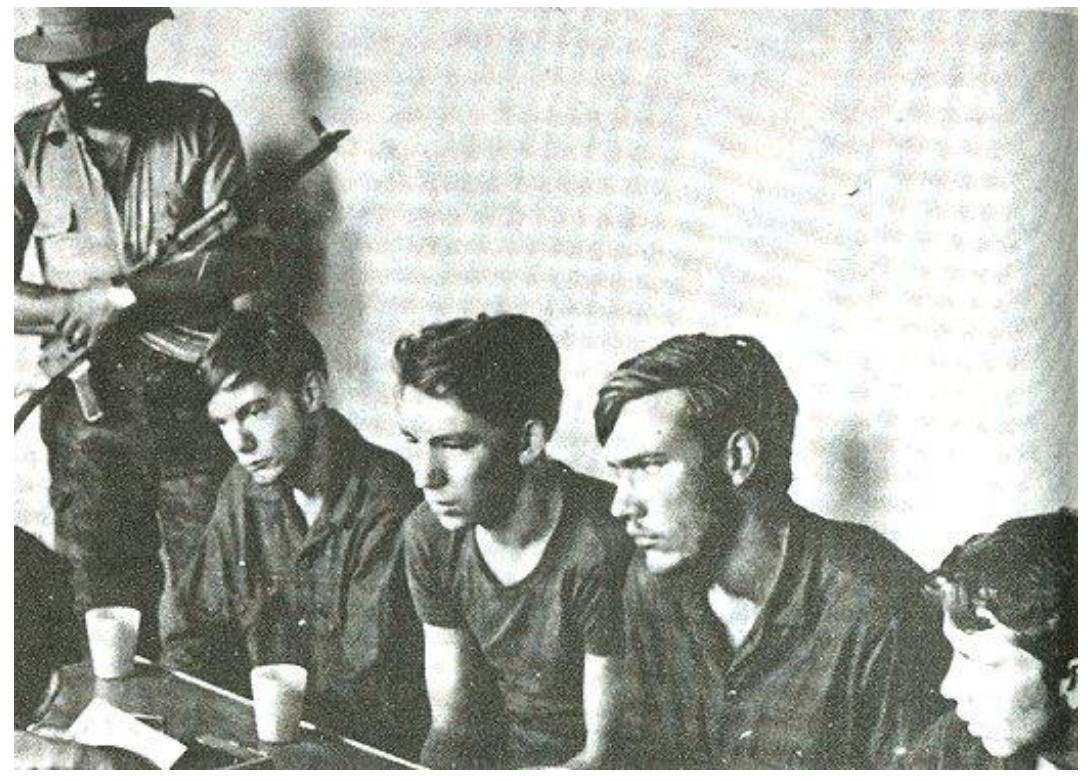

The Angolans scored another propaganda coup when two of the four captured soldiers were displayed at a press briefing in Lagos, Nigeria on 
18 December 1975. Subsequently, images of two handcuffed white SADF soldiers were widely syndicated and published in newspapers around the world.

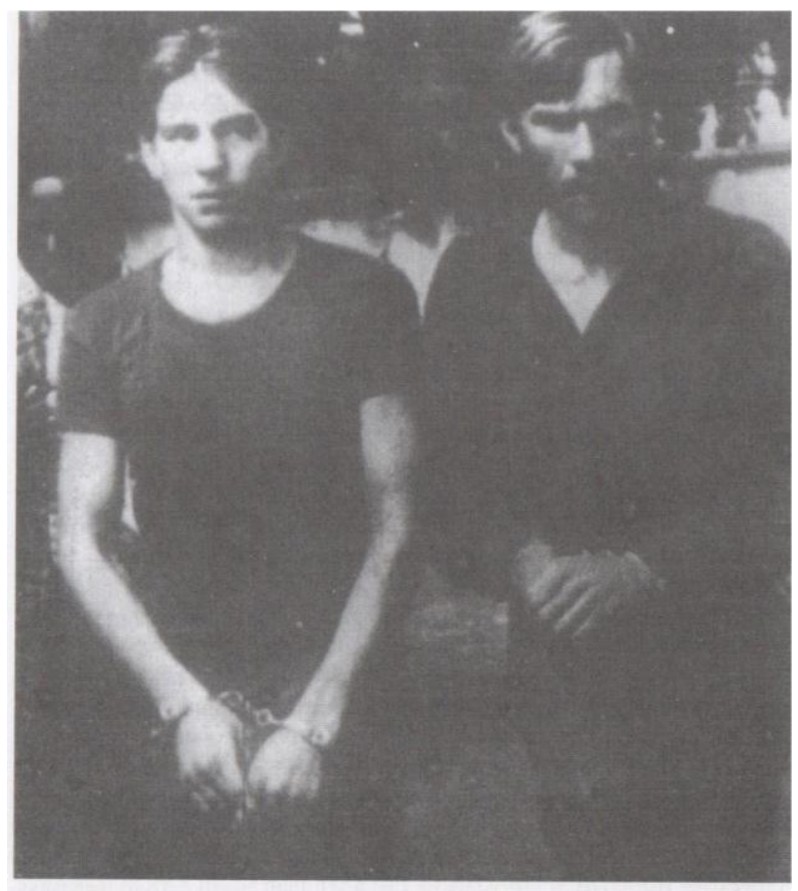

This photograph and details of interviews with the captives were prominently reported in the South African press which served to expose the sham of Pretoria's previous denials that its forces were involved in Angola. ${ }^{26}$ The photograph appeared on the front page of the Rand Daily Mail on 19 December 1975, which offered the following comment:

A single photograph ... brought home, perhaps more than anything else so far, the implications of the country's involvement in the Angolan conflict ... Here were the first South African soldiers in a quarter of a century to be taken prisoner of war - two bewildered youngsters enduring public humiliation paraded before an international audience by their MPLA captors ... Somehow nothing 
that has gone before - not even any of the tragic deaths in unidentified 'operational areas' - has conveyed to the same degree the direct human consequences of becoming embroiled with antagonists in southern Africa. ${ }^{27}$

The historian Bernard Magubane has expressed similar sentiments. He notes that "... the un-nerving picture of young white recruits manacled together as POWs in African hands [reversed] the traditional image of the whites as supermen and captors and blacks as Lilliputians and prisoners ...". ${ }^{28}$ These images exposed the deficiencies of the SADF as well as the vulnerability of its soldiers. And they fuelled the groundswell of dissent and resistance, particularly amongst black youths, to the apartheid regime.

Unknown to the South African public, three Cubans had been captured by Battle Group Zulu in separate incidents between 12 and 15 November 1975. They were held at Silva Porto (Bié) by UNITA where they were interrogated before being transferred to Pretoria for medical treatment. ${ }^{29}$ This marked a departure from previous practices whereby the SADF turned captured FAPLA soldiers and their support forces (i.e. Cubans) over to UNITA once they had been interrogated. ${ }^{30}$ On one occasion, UNITA forces had apparently executed seventeen POWs prior to their forced withdrawal from Silva Porto in the face of a combined FAPLA/Cuban counter-offensive. ${ }^{31}$ The Chief of the SADF, Admiral H Bierman, recognised that the Cubans might prove valuable in securing the release of SADF POWs. In an internal memo, he noted that, because the MPLA now held a number of SADF members, it was necessary to hold Cuban captives for future negotiations and a possible exchange. His memo advised that captured Angolans and Cubans were to be treated as POWs and accordingly granted the status and treatment required by the rules of war. ${ }^{32}$

Bierman's memo was informed by the knowledge that a further three SADF troops had been taken prisoner near Calucinga, about $400 \mathrm{~km}$ south-east of Luanda. These members of $5 \mathrm{SAI}$, who comprised part of Battle Group Orange, were captured in their Entac missile vehicle in circumstances which were not clear to Military Intelligence. ${ }^{33}$ The whereabouts of the missing South Africans remained unknown until they were displayed to the press in Luanda on 8 January 1976. Then they were transported to Addis Ababa where they were paraded before the international media at the Organisation of African Unity (OAU) summit held in the 
Ethiopian capital from 9 January. ${ }^{34}$ Once again, images of the captured SADF conscripts were syndicated throughout the world.

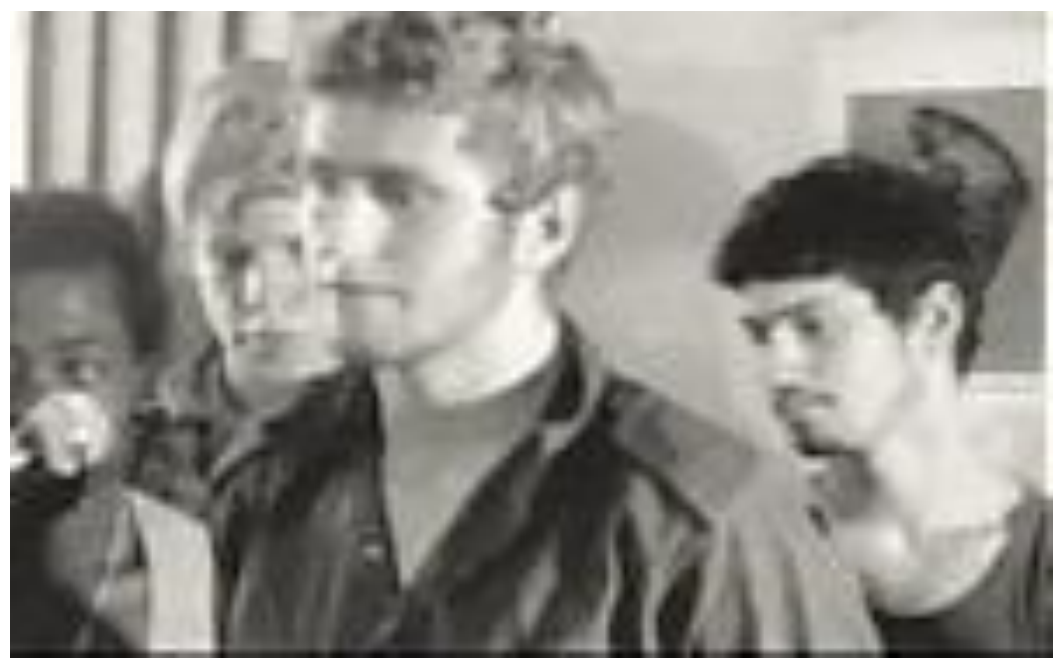

Footage was screened by the newly established SABC television which depicted the three young national servicemen being made to spell out their names. ${ }^{35}$ They were identified as:

- Rfn Andries Hendrik Potgieter

- Rfn Lodewyk Johannes Christiaan Kitshoff

- Rfn Petrus Jacobus Groenewald.

On 16 February 1976, the SADF issued a directive to the press in which the Minister of Defence requested that no further photographs of South African soldiers being held captive by the MPLA be published. An explanatory note added: "Defence HQ say they and the Minister [are] being flooded by objections from relatives to publication of such pictures" ${ }^{36}$ The directive was sent to all newspapers via the South African Press Association (SAPA) announcing that a ban on reports about the POWs would take effect from 27 February ${ }^{37}$ But this belated attempt at damage control could not offset the personal humiliation of the POWs nor the diplomatic setback suffered by the South African government. Indeed, the revelation of South Africa's aggression in Angola turned the opinion of wavering African states against the apartheid regime. What little support the Vorster government had 
mustered for its backing of the pro-Western factions in the Angolan civil war as a result of its policy of détente evaporated. On 11 February 1976, the OAU formally recognised the MPLA as the legitimate government of the People's Republic of Angola (PRA). ${ }^{38}$

In the absence of a permanent ICRC delegation in the country, the South African authorities approached the office of the local Red Cross organisation to assist it to explore contacts with the ICRC headquarters in Geneva to open up channels to negotiate terms for the release of the POWs. ${ }^{39}$ The South African government also asked its permanent representative in Geneva to convey a request to the ICRC to intervene in the matter. The ICRC indicated that it was willing to monitor the treatment of prisoners by all parties and use its good offices to liaise between adversaries. Accordingly, an ICRC mission, led by the Delegate General for Africa, made several representations to the envoys of member states at the OAU's special summit meeting in Addis Ababa. The mission's task was ostensibly to remind parties in the war-torn sub-continent of the fundamental principles set forth in international humanitarian law. ${ }^{40}$ But the ICRC delegation used the occasion to request the PRA for permission to visit the South African POWs. It suggested that the South Africans be exchanged for prisoners held by UNITA and the FNLA. This request was not spurned outright by the Angolans who agreed to give the matter careful consideration. ${ }^{41}$

Meanwhile, the ruling National Party government sought to defuse mounting criticism of the Angolan incursion occasioned, in part, by revelations of the capture of SADF personnel. On 26 February 1976, Minister of Defence, PW Botha made a speech in the House of Assembly in which he finally admitted South Africa's involvement in Angola but still remained evasive about the details of Operation Savannah and its objectives. ${ }^{42} \mathrm{He}$ assured the public that the government was committed to securing the release of the POWs as expeditiously as possible. Subsequently, the POWs' next of kin were sent copies of the relevant pages of Hansard that included Botha's speech. However, parents were not necessarily satisfied by the impersonal and vague assurances given by Botha. For instance, Groenewald's parents addressed queries to Botha to ascertain what exactly was being done by the South African government to ensure the safe return of their son. In response to this and other representations, Botha's office sent letters to the next of kin of all seven POWs to assure them that no effort was being spared to secure the 
early release of the SADF soldiers. But the failure to mention specific strategies that were being pursued did not provide much comfort for the POWs' next of kin.

The (white) public were shocked to learn that SADF soldiers were being held captive by the Angolans, and government attempts to cover up the debacle were slated in the press. The liberal press tended to criticise the government for failing to take the electorate into its confidence about its clandestine operations but registered their full support for the captive soldiers as victims of the state's deceitfulness. The leader of the Progressive Reform Party, Colin Eglin, offered his services to intercede in the clandestine negotiations between the South African and Angolan governments to secure the release of the POWs. If the liberal opposition were reluctant to exploit the situation for the sake of political advantage, the right-wing harboured no such scruples. Bob Whyte, editor of the American newspaper Conservative Chronicle, insisted that the South African government declare war on Angola if the POWs were in any way harmed. From closer to home came numerous offers to intervene on behalf of the POWs, including operations to free them despite a singular lack of intelligence about their place and conditions of captivity. Some of these harebrained schemes seem to prefigure the plots of Rambo's rescue missions to free American MIAs in Vietnam. Strident voices called for the SA government to act without thought for the consequences. A certain Geldenhuys insisted that government demand the release of the POWs from a position of strength as the invasion of Angola had revealed the vulnerability of FAPLA to the superior operational capacity and firepower of the SADF forces. Such uninformed opinion took no account of the escalation of Cuban troops in Angola nor the sensitivity required in the handling of delicate matters by the apartheid state. ${ }^{43}$

The first hint to the public that the SADF had captured Cubans during Operation Savannah was given with the screening of the propaganda film Brug 14 by SABC TV on 29 April 1976. This was timed to precede the Minister of Defence's no-confidence debate. During a subsequent exchange with Progressive Reform Party MP, Harry Schwarz, PW Botha admitted that there was substance to the rumours. ${ }^{44}$ After a brief period of recuperation at 1 Military Hospital, the Cubans were transferred to the Voortrekkerhoogte detention barracks. Here, the ICRC was permitted access to the prisoners and supervised visits were arranged at regular intervals. ${ }^{45}$ ICRC representatives ascertained whether the conditions under which they were being held conformed to the provisions of the Geneva Conventions 
pertaining to the internment of POWs. Eventually, the Cuban POWs were displayed to the press on 25 September 1976. They were identified as:

- Sgt Ezequiel D. Garcés Mustelier

- Pvt Roberto Morales Bellma

- Pvt Carlos Alberto Mani-Mesa

The South African government was convinced that, by revealing its hand, they would have greater leverage to secure the release of their own POWs. They believed that the Cubans might be amenable to a prisoner swap and hoped that they would put pressure on the Angolans to enter into negotiations towards this end. However, not everyone shared this point of view. A newspaper report expressed the concern that "the Cubans may not be as interested as we are in securing the release of our prisoners". 46 The SADF mouthpiece, Paratus, did not speculate about the possibility of a prisoner exchange but chose, instead, to highlight the human interest angle of the story of the Cubans in captivity. ${ }^{47}$ Given that their target audience was national servicemen, the editor of Paratus seemed to think that such a focus might provide assurance that all POWS would be returned to their families. The South Africans went as far as extending an invitation to the Cuban POWs' kin to visit them at the expense of the taxpayer. ${ }^{48}$ The appeal of such overtures depended on whether Havana felt obliged to do all within its power to repatriate its soldiers. No less an authority on Castro's Cuba than Piero Gleijeses conceded that it is difficult to gauge the reaction of the island's population to Operation Carlota, the name given to the counter-offensive against South Africa and its surrogates. ${ }^{49}$ But it is likely that Cuban soldiers were more expendable than their South African counterparts.

If the South Africans believed that the Cubans would pressurise the Angolan government to negotiate the exchange of POWs, this proved to be a mistaken assumption. Initially, all representations made by the ICRC on behalf of the South African government were rebuffed by the government of the PRA. Although the Angolan representative to the UN Security Council debate made a statement in March 1976 that the South Africans held captive would be treated as POWs, this standpoint was contradicted by others made in private. In April of that year, an ICRC delegate met with the Director General of the Ministry of Information who was appointed by Luanda to liaise with the ICRC. On this occasion, the ICRC was informed that, "as a state of war was never declared between Angola and South Africa, the South Africans could not be considered as prisoners of war". 50 Moreover, the Angolans held that the issue of the POWs was only one of a number of matters 
that had to be addressed and that they were not prepared to enter into secret negotiations dedicated to this single issue. And the ICRC was "asked to put an end to its insistence in favour of the South African POWs, as it was considered as foreign to its competence". ${ }^{51}$ This was not merely a snub but a rejection of the ICRC's authority. An ICRC delegate was eventually informed by the PRA's Director of International Organisations at the Ministry of Foreign Affairs to refrain from making further representations on the matter and to close its office in Luanda. ${ }^{52}$ The ICRC duly withdrew its delegation from Luanda at the end of October 1976.

Under the circumstances, the South African government decided to pursue a parallel strategy whereby they would make a direct approach to the Angolans. To this end, a meeting was held between representatives of the Angolan government and the South African DFA at the Angolan/Namibian border on 8 June 1976. On this occasion, the former gave the assurance that the seven SADF members would not be treated as mercenaries but as POWs. This meant that they would not be subjected to trial and summary execution. However, no progress was made towards an agreement pertaining to a prisoner exchange.

At home, the South African government sought to enforce its embargo on press reports pertaining to the captivity of POWs. It threatened to invoke the Defence Act (No. 44 of 1957) to prevent the media from reporting further on the POWs. It insisted that any publicity would hamper negotiations to free the POWs, and that this adversely affected the relatives of the POWs. The authorities were prompted to act after an unsubstantiated report that the POWs had been shot apparently caused considerable anxiety amongst the latter's next of kin. ${ }^{53}$ The Defence Ministry expressed concern that such reports would be detrimental to the POWs' families and circulated a confidential note to the press in which it "pointed out that any publication of reports and photos ... will definitely be detrimental to the cause and safety of the POWs". 54 However, not all members of the National Press Union (NPU) were prepared to comply with government's wishes to keep these matters under wraps. For instance, Die Afrikaner published 18 major articles and letters on the subject between 6 February 1976 and 15 September $1978 .^{55}$ It was not censured, but the Namibian-based newspapers, the Windhoek Advertiser and Allgemeine Zeitung, were excluded from the forum at which SADF representatives provided the press with briefings when they ran foul of the NPU's agreement with the Defence Committee. In addition, the accreditation of the Rand Daily Mail's defence correspondent, Bob Hitchcock, was withdrawn after his exposure of security 
lapses at a military base irked the Minister of Defence. It did not help Hitchcock's case that he was critical of press censorship and that he took his role as 'watchdog' too seriously for the liking of the Defence Ministry's Directorate of Public Relations. ${ }^{56}$ Whilst the mainstream press refrained from mentioning the POWs for a year, government was unable keep the lid on the subject entirely.

News that another SADF soldier had fallen into Angolan hands on 28 August 1976 was initially withheld from the public. The absence of Rfn Eugene de Lange of Germiston's Bravo Group Commando from his base in the operational area was noted. A Military Intelligence brief stated that De Lange had become lost in his vehicle near Macusso and had crossed the kaplyn (cut-line) after which he had been captured by a FAPLA/Cuban patrol. ${ }^{57}$ Following a search by his unit that failed to ascertain his whereabouts, De Lange was declared to be 'missing in action'. His parents were informed three weeks later. According to a SADF communiqué, De Lange had been captured by FAPLA after straying across the Angolan border.

When De Lange's capture became public knowledge it added to the consternation of the public and that of the POWs' families alike. By now the latter had become sufficiently disillusioned with the Defence Ministry's inability or reluctance to give them straight answers to their queries about whether their sons would be released or not. Consequently, they decided to go over PW Botha's head. In October 1976 they petitioned government for a meeting with Prime Minister BJ Vorster. They were granted an audience with Vorster at the Union Buildings on 4 November 1976. Vorster assured the next of kin that their sons and husbands would not be treated as mercenaries but as POWs by the Angolans. Having put their minds at rest that the men would not be summarily executed, Vorster proceeded to explain that the ICRC was involved in delicate negotiations with the Angolan government to secure the release of their loved ones. He appealed to the next of kin not to divulge any information to the press about the meeting and confided that the press had consented not to report on the matter in the best interests of the POWs. Vorster attributed the lack of information about the treatment of POWs to the difficulties in dealing with an 'uncivilised' nation, likening it to the situation which the USA had encountered in Vietnam. When a parent commented that she did not know that her son was on the border let alone deployed in Angola, the point was dismissed as having no bearing on the discussion of the matters at hand. In response to a written question whether the POWs had agreed to render service outside of the country and whether government had acted legally in sending troops into Angola, 
both Vorster and Botha replied that the matter had been dealt with in Parliament and that copies of the Minister of Defence's speech would be forwarded to all those present. ${ }^{58}$ Far from commiserating with the families of the POWs, Botha dismissed their disquiet about the situation with an intolerance which bordered on contempt. This was both tragic and ironic given that the captured SADF soldiers had been involved in operations on foreign soil at the behest of the selfsame government.

A follow-up meeting was held in the Minister of Defence's Pretoria office on 18 November 1976. Botha used the opportunity to announce that monthly visits by SADF chaplains would be arranged and that such visits would allow POWs' families to be kept abreast of the progress of negotiations being conducted by the ICRC. He invited family members to communicate with his office if there was a need to do so. Botha also stressed the necessity of communicating with the POWs when the opportunity arose, and to do so in such a way as to maintain their spirits and morale. He took the strongest exception to a query by an unnamed parent who had the temerity to ask whether the POWs were expendable to the SADF. Botha insisted that this was not the case and that it would never be so while he was Minister of Defence. Botha did, however, concede that it was a sensitive situation and that he did not hold all the aces. He also stressed that "publicity, of whatever nature, in this matter will certainly jeopardize, if not wreck, our efforts to secure the release of your son and his comrades."

On 14 December 1976, an item appeared in The Daily News, lamenting the fact that eight South African POWs would be spending Christmas in Angolan prisons without any prospect of being released in the foreseeable future. The report noted that "far from being an issue of national indignation, their plight is scarcely mentioned in the press because of the restraints imposed on newspapers in terms of the Defence Act". The newspaper expressed its sympathy for the families of the POWs. In a mild critique of the National Party government, The Daily News reporter opined that "the servicemen are the victims of a diplomatic impasse that has arisen from South Africa's abortive involvement in the Angolan War". ${ }^{60}$ The report incorrectly stated that there was no direct communication between the South African and Angolan governments in respect of the POWs, and that they had not been visited by ICRC delegates. In fact, the reporter and his public were ill-informed. As the Geneva-based organisation intimated in its Annual Report for 1976: 
The ICRC intervened ... on behalf of the eight South African soldiers detained in Luanda and who, in its opinion, should be granted prisoner-of-war status. ${ }^{61}$

But it was precisely the Angolan government's perception of bias in favour of the South Africans that made it wary of the ICRC's agenda. South Africa's permanent representative in Geneva interpreted this to mean that Luanda rejected the ICRC's claim to be an "impartial non-political organisation". ${ }^{62} \mathrm{He}$ reckoned that the Angolans were suspicious of the ICRC's neutrality on account of the racial composition of its agencies, which had no representation by Third World countries. Thus the ICRC had to approach Luanda with considerable caution as it did not wish to alienate black African states. ${ }^{63}$ It was also hamstrung by the lack of an office in the Angolan capital and so all negotiations had to be directed through the Geneva office.

Following an appeal in December 1976 by the President of the ICRC, Alexandre Hay, to the Angolan authorities, the South African POWs were allowed to correspond with their families. The ICRC was not allowed access to the POWS and only acted as an intermediary delivering letters and parcels from their families. ${ }^{64}$ The content of these letters suggested that both parties were kept in the dark or instructed not to divulge information about the ICRC's interventions to secure their release. The Defence Ministry sought to control or, at least, censor press statements regarding the receipt and content of these letters. Botha insisted that the intercessions of the ICRC might be compromised if it were to become public knowledge that the South African government was negotiating with its enemies via intermediaries. But some of the parents' patience with the government's chosen course of action was wearing thin. Three sets of parents wrote a joint letter to Botha complaining that they were sick and tired of being fobbed off by being told that the negotiations were 'sensitive' or that, if they were to pursue their own course of action, they would find themselves in contravention of the Official Secrets Act. ${ }^{65}$ Thus, the POWs' next of kin were constantly subjected to a mixture of intimidation and cajolement to induce them to remain part of the process that the government sought to control.

After making little progress in their dealings with the MPLA, the South Africans sought to short-circuit the negotiation process by approaching the Cubans through a third party. Communications with the Cuban United Nations (UN) representatives in New York were facilitated by a certain Klingenberg acting on 
behalf of South Africa's ambassador to Washington, RF (Pik) Botha. But the Cubans proved reluctant to exchange the eight South Africans being held in Luanda for their own POWs in Pretoria as they believed that the SADF and/or their surrogates held more of their soldiers in captivity. A number of their troops were obviously killed or missing in action, and one had apparently defected. ${ }^{66}$ Botha proposed that the Cubans send a secret commission to South Africa to satisfy themselves that there were no more than three Cuban POWs. ${ }^{67}$ In a characteristically grandiose but empty gesture, he proposed to offer himself to the Cubans as a hostage in exchange for the release of the South African POWs. It is not clear whether this proposal was rejected by the South African or Cuban government as no evidence has been found to show that the visit occurred. Still, the Cubans accepted South African assurances and communications continued through the offices of the third party. But the South African proposal that the eight South African POWs be exchanged for the three Cubans elicited the following response from the latter's government:

We insist on four for three. We will make the necessary guarantees for the other four. South Africa gave Cubans to Savimbi who killed them. We also have proof that some prisoners given to Savimbi are unaccounted for. That is why eight for three is unacceptable. ${ }^{68}$

For its part, the South African government insisted that it was not prepared to make any exchange that did not ensure that all eight POWs were released, that it could not possibly entertain the idea of dividing the POWs, and that it would prefer to hold out for an agreement that guaranteed the release of all POWs simultaneously.

Unlike his predecessor, the new Chief of the SADF, General Magnus Malan, was privately prepared to concede that the Cuban POWs had little or no exchange value. He also reckoned that the MPLA government was waiting for an opportune time to use the POW issue to hold South Africa to ransom by insisting that it pay war damages. ${ }^{69}$ Under the circumstances, the Minister of Defence, PW Botha, requested the newly appointed Minister of Foreign Affairs and his namesake, Pik Botha, to step into the breach as the Defence Ministry had reached a 'dead end' ${ }^{70}$ The Department of Foreign Affairs (DFA) assumed charge of co-ordinating the efforts that were conducted with a range of organisations on a number of fronts to secure the release of the POWs. ${ }^{71}$

Meanwhile, agents of the SADF's Military Intelligence made contact with the dissident MPLA faction led by Nito Alves (known as 'Nitistas'). They initially 
rejected sponsoring Alves who planned a coup to overthrow the incumbent MPLA leader and PRA President, Agostinho Neto, on the grounds that it was not South African policy to interfere in the domestic affairs of other countries. If the irony of this position was lost on the South Africans, they at least realised that the prospect of a change of regime in Angola was hardly a guarantee that the POWs would be released. Prior to the planned uprising, the Alves faction contacted the South African government with a proposal that it be paid \$US2,5 million in return for the safe delivery of the POWs to Zaire. On 27 May 1977, the Nitistas stormed Sao Paulo prison and freed eleven comrades, along with hundreds of common criminals and UNITA and FNLA members. The American and British mercenaries ${ }^{72}$ wisely chose not to make good their escape for the coup was crushed and a purge of the Nitistas ensued. ${ }^{73}$ Although it is not clear whether the South African POWs were caught up in the failed coup, the apartheid regime remained ready to sponsor any activities that undermined the MPLA government. Accordingly, a token amount of R80 000,00 was earmarked for the Alves group from a secret Military Intelligence fund. And the Bureau for State Security (BOSS) indicated a willingness to continue to cultivate MPLA factionalism, especially if there was any prospect of it combining forces with UNITA and the FNLA against the ruling party. ${ }^{74}$ Whilst the South Africans were apparently not the only party interested in exploiting MPLA factionalism, ${ }^{75}$ the tack used by Military Intelligence proved to be another dead end.

Another meeting was arranged by the government with the next of kin of the POWs in Cape Town on 2 June 1977. PW Botha introduced his namesake as the interlocutor with the Angolan government and intimated that Pik Botha was better positioned to update the next of kin on developments. But Minister of Defence Botha was quick to add that this did not mean that the Department of Defence was abrogating its responsibilities to the POWs; rather that the DFA was in a better position to proceed with the negotiations. The Ministry of Foreign Affairs (MFA) delivered letters from the eight POWs to their next of kin and explained that these had been obtained through his contact person in Vienna, a Mr Mondale. Botha instructed the next of kin to reply to these letters (in English) in tones that were positive but which did not raise the expectations of their next of kin for release as they might be disappointed. He reported that the POWs were in good health and were being adequately provided for. The next of kin raised questions about whether they were regarded and being treated as political detainees or POWs. The MFA sidestepped the question and responded that the main issue was that they were being treated well and that their status was a secondary matter. He added that his own 
channel of contact with the Angolans was more likely to yield results than the representations of the ICRC but that all avenues would be explored, and that one or other channel would yield the desired result. Pik Botha gave repeated assurances that the government was leaving no stone unturned in its efforts to obtain the release of the POWs and that he was taking a personal interest in the issue; indeed, treating it as if the POWs were his own sons. ${ }^{76}$ Botha might have come across as sincere but there is no doubt his bluster was part of a charm offensive to ensure that the POWs' next of kin forsake any idea of exploring alternative diplomatic and legal options to secure their release. Pik's style was certainly a departure from PW Botha's rather brusque manner in dealing with the POWs' relatives.

In the Minister of Defence's subsequent written communication with the POWs' next of kin, they were assured once again that everything possible was being done to secure the release of their loved ones. But the letter included a veiled warning when it noted that such efforts should not be allowed to threaten the security of the state or disclose the identities of well-respected figures who were acting in the interest of the country. PW Botha admitted that he was unable to give guarantees that their release was imminent. ${ }^{77}$ This was little consolation for the POWs' next of kin who were expected to be satisfied with the Defence Department's arrangement of monthly visits by welfare officers from local Commando units in the absence of concrete information about the progress of negotiations in respect of their release. It is apparent from the records that the parents and loved ones suffered emotional distress as a result of the incarceration of their child/sibling/partner in an Angolan prison. Emotional distress was frequently exacerbated by financial loss. At least one wife lost a child and then proceeded to file for divorce and promptly fell pregnant again. The parents expended considerable energy to ensure that their son's erstwhile spouse did not continue to receive his salary. In another case, the elderly parents of a POW became ill and ran up huge medical bills, which they asked the SADF to assist them to pay. These seemingly mundane details of the travails of the POWs' next of kin are mentioned so as to alert us to the fact that this story has a human dimension, and that both soldiers and their next of kin were to some degree victims of the apartheid state's decision to wage an undeclared war in Angola.

Throughout the protracted negotiations to secure the release of the POWs, the South African government took measures to defuse the growing criticism of its handling of the POW issue by resorting to censorship and excluding defence 
correspondents and/or editors from briefings by the SADF's press liaison officers. This was partly motivated by a wish to prevent opposition, especially the right-wing, from scoring political points out of the POW issue. The aforementioned Herstigte Nasionale Party (HNP) mouthpiece, Die Afrikaner, attacked government for its socalled dishonesty during the war and its subsequent 'betrayal' and alleged abandonment of the POWs in the hands of their black captors. The HNP believed that government's handling of the POW issue provided it with ammunition to castigate the NP in its election campaign. At its congress in September 1977, the HNP passed a motion that Die Afrikaner should withdraw from the NPU and seek to raise public awareness about the POWs. Die Afrikaner reckoned that the news blackout was affected in order to protect the political reputation of Botha who, as Minister of Defence, had exhibited a weakness in dealing with the Angolans/Cubans to secure the release of the POWs. ${ }^{78}$ Botha insisted that his integrity had been impugned and that he had been defamed. Consequently, both the Chief of the SADF and the Minister of Defence laid charges against Die Afrikaner and Botha threatened that, if the NPU did not force it to adhere to their agreement, he would sever his working relationship with the body. ${ }^{79}$ This was an idle threat because the newspaper had already taken the decision to withdraw from the NPU. Undaunted, Die Afrikaner repeated its charge that nothing was being done by government to effect the release of "captive young Afrikaners in Angola" in its issue of 21 October 1977. ${ }^{80}$ The article and its accompanying photograph of two handcuffed South African POWs (see above) was obviously regarded as likely to reflect poorly on government's handling of the issue and to have dealt a blow to public morale. ${ }^{81}$ Prime Minister Vorster's press secretary referred the matter to the Press Council for action. ${ }^{82} \mathrm{He}$ also indicated that the Minister of Defence was prepared to testify in camera to the council that Die Afrikaner's charges were without foundation. However, it was stated that it was likely to jeopardise the ongoing negotiations if details were to be revealed in a public forum. ${ }^{83}$ While the mainstream media accepted government's argument for the need of secrecy, The Afrikaner was not prepared to toe the line. HNP leader Jaap Marais referred to the matter as a scandal and suggested the withdrawal of South African troops from Angola should not happen before the POWs had been freed. Needless to say, the NP government did not heed Marais' call but neither did it take any action against Die Afrikaner on account of the sensitivity of the POW issue. ${ }^{84}$ 


\section{SWAPO's solitary captive}

The POW saga entered a new and more complicated phase with the capture of Sapper GJ (Johan) van der Mescht by SWAPO. Van der Mescht's ten-man section was ambushed by PLAN guerrillas at a water hole at Elundu about $6 \mathrm{~km}$ from the Angolan border on 19 February 1978. ${ }^{85}$ According to a Military Intelligence brief, SWAPO captured three members of the section but killed two of these before they crossed the kaplyn. ${ }^{86}$ A battle group codenamed Juliet was tasked to pursue the PLAN unit into Angola to secure the release of Van der Mescht but was unsuccessful. ${ }^{87}$ Following an SADF briefing, the South African media reported that two SADF members had been killed and seven wounded in the incident, and that Van der Mescht had been abducted.

The South African conscript was initially detained for several weeks by SWAPO at its regional headquarters at Haipeto in southern Angola where he was treated for multiple wounds. He was then transported to Cassinga where he was interviewed and photographed by the Swedish journalists Per Sanden and Tommy Bergh. ${ }^{88}$

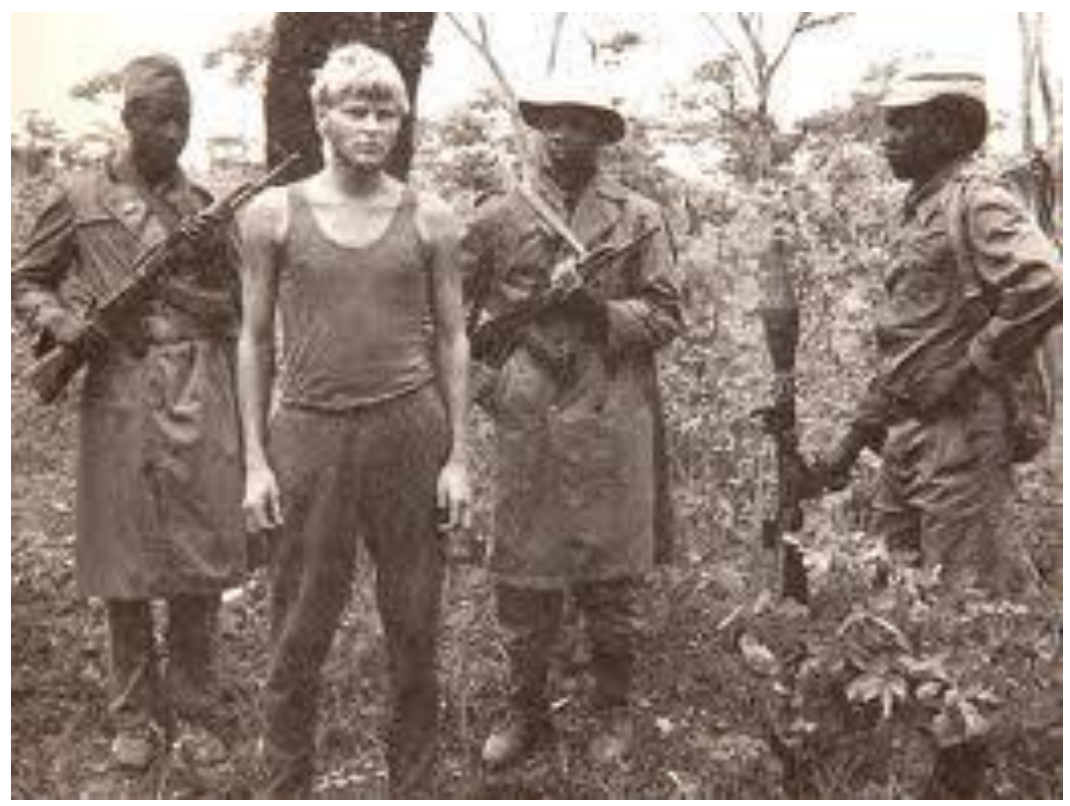


Van der Mescht was subsequently transferred to Lubango and then flown to Sao Paulo prison in Luanda on 9 March 1978. Following interrogation by his captors, he was paraded before the international media by SWAPO leader Sam Nujoma, and on this occasion issued a statement that effectively condemned the SADF's role as an occupation force in Namibia. He stated, inter alia, that the SADF had 25000 troops in Namibia and that they were busy training UNITA to serve as a proxy against PLAN and FAPLA. Van der Mescht also claimed that his entire section - apart from himself - had been killed. ${ }^{89}$ A SADF situation report (sitrep) meant for internal consumption tersely responded to SWAPO's claims with the statement that: "Van der Mescht's declaration in Luanda will not be dignified with comment because it is a propaganda statement made under pressure". ${ }^{90}$ There is no doubt that the statement was made under duress. In a letter to his wife (dated 24 April 1978) and smuggled out of San Paulo prison, Van der Mescht tells her not to believe anything he said in "that T.V. interview. I have said it only for my own safety. Now I wish I didn't do it. I don't know what was said in S.A. papers but what was said here is one big lie." While Van der Mescht had to live with the knowledge that he had disavowed his country, his family had to live with accusations that he was a traitor who had crossed the border into Angola of his own accord. ${ }^{91}$

Van der Mescht was kept in solitary confinement for eight months, isolated from his inmates who included political prisoners, mercenaries, members of the FNLA and UNITA, as well as renegade SWAPO cadres. It seems that he had no direct contact with the other eight South African POWs who were kept in a separate part of the prison. But he obviously learned of their whereabouts and was presumably given news of their situation by the ICRC delegates. In a letter to his parents (dated 24 April 1978), he commented that his countrymen were being better treated than he was. This he attributes to his being a SWAPO rather than a Cuban prisoner. But he believed that his status as a POW afforded him greater prospect of being released. Van der Mescht wrote:

Unlike the others I am a POW and can expect to be exchanged as soon as SWA becomes independent. ... but I don't know what will become of those caught in Angola.

His first assertion was, strictly speaking, correct. He was a regular soldier who had been in the uniform of the SADF on Namibian soil when he was captured whereas the others were captured on Angolan soil without any insignia that identified them as SADF personnel. However, Van der Mescht's faith in the LOAC 
was ill-founded as South Africa did not adhere to the Geneva Conventions, and dealings with SWAPO proved more difficult than the PRA. Although he was to be released many years before Namibia's independence, the other South Africans were to spend less time than him in captivity.

The South African government's initial silence - verging on paralysis - in the face of the capture of one of their troops played into the hands of SWAPO who capitalised on the situation. It provided SWAPO with the wherewithal to discredit the South African occupation forces in Namibia and impress upon the world that PLAN was capable of mounting an effective insurgency. SWAPO's administrative secretary, Moses Garoeb, remarked that the organisation would only consider the release of Van der Mescht if the request was made through the United Nations or Western Contact Group. He added: "We are at war with South Africa and any question on the exchange of war prisoners can only be done through these organisations. South Africa should know that we are a force to reckon with." 92 Nonetheless, Garoeb provided assurances that Van der Mescht and the other SADF troops captured earlier were being treated according to the terms governing the status of POWs laid down in the Third Geneva Convention but that the same could not be said of the South Africans' treatment of Namibian political detainees and POWs.

Garoeb's statement was borne out by the treatment of the so-called 'Cassinga detainees'. On 4 May 1978, the SADF launched Operation Reindeer, a three-pronged attack on SWAPO bases north of the Angolan/Namibian border. It included an aerial assault on Cassinga that housed civilian refugees, as well as ground assaults on Chetequera and Dombondola that netted over 100 prisoners. Although these prisoners were rounded up at the latter bases, they came to be known as the 'Cassinga detainees'. They were transported to northern Namibia and thence to the Hardap Dam near Mariental where they were interned. They were subjected to interrogation and alleged maltreatment, which became the subject of an international campaign to raise awareness of South Africa's violation of the provisions of the Geneva Conventions for the treatment of POWs. Certain detainees were charged under South African laws, such as the Terrorism Act, that were applied to Namibia, whilst those released reported that they had been tortured..$^{93}$ But there were no means of independently verifying these allegations until the ICRC was granted access to the Mariental camp. And this only transpired when the South Africans recognised 
that maintaining good terms with the ICRC might facilitate the release of Van der Mescht.

In June 1978, the US deputy representative to the UN Security Council, Donald McHenry, visited Luanda to ascertain the conditions under which imprisoned American mercenaries were being held in the Angolan capital. At the request of the DFA, he made inquiries about the South African POWs and offered the assistance of the US government in facilitating a prisoner exchange. He reportedly received a non-committal response from the Angolan Prime Minister (PM) who noted that talks with the South Africans in Geneva over the issue had broken down. He added, "Angola was willing to resume the talks and had no interest in devoting its scarce resources to the care of expatriates." 94 But another remark by the Angolan PM revealed what might have been a sticking point in the negotiations. He believed that "the South African practice was to kill Angolans and to take no Angolan prisoners". 95 As we have seen, there is evidence to suggest that the SADF tended to turn captured FAPLA troops over to UNITA and that the surrogate force killed them. However, this practice was modified when the SADF realised that Angolan prisoners might become valuable bargaining chips in their dealings with the PRA. In fact, the SADF held six FAPLA members in Oshakati, five of whom had been captured in Ovamboland. It seems that these Angolans had been apprehended after crossing the border in search of provisions and not following combat. The sixth detainee had received training by FAPLA and was captured in Angola by UNITA and presumably handed over to the SADF. ${ }^{96}$ The Angolan detainees were transferred to the Mariental camp.

The South African authorities continued to pursue other avenues in attempting to secure the release of the eight South Africans held by the Angolans/Cubans. Whilst the role of BOSS appears largely inconsequential to the negotiation process, it should be noted. Because the bureau's chief, General Hendrik van der Bergh, had the ear of Prime Minister Vorster, his agents were not subject to standard diplomatic procedures in their dealings with the Angolans. Intelligence gleaned from behind-the-scenes contacts with the MPLA government indicated that they were prepared to exchange SADF prisoners for Angolan and Cuban members of the armed forces on a one-for-one basis. The MPLA apparently added the proviso that the return of any other POWs would cost the South African authorities R1 million per head. Such an exchange would also be subject to the condition that South Africa ceased its support of UNITA. In his capacity as Chief of the SADF, 
General Magnus Malan approved the suggestion that Mr Rothman of BOSS should be encouraged to pursue contacts with the Angolan President, Agostinho Neto, via unofficial channels. He also proposed that the Ruacana hydro-electric scheme be included in the equation but was advised that Neto was not likely to approve this because any agreement with the South Africans might be rendered null and void once Namibia attained its independence. ${ }^{97}$

The prospects for the release of the South African POWs and their Angolan/Cuban counterparts improved when the PRA agreed to accept the bona fides of the ICRC and to the establishment of a Red Cross Society in the country. Delegates from the Geneva-based organisation paid periodic visits to Luanda and Pretoria for the purpose of inspecting conditions of the POWs held by both sides and negotiating an exchange. This was finally achieved on 2 September 1978 when the eight South African POWs held by the Angolans/Cubans were released in exchange for three Cubans and eight unidentified Angolans at N'giwa near the AngolanNamibian border. ${ }^{98}$ The return of the SADF members was turned into a media spectacle by the government which was rewarded with banner headlines. ${ }^{99}$ But the government's efforts to derive some political mileage from its handling of the episode was undercut by reports of tensions between PW Botha and certain parents of POWs over his alleged failure to keep the families properly informed of developments. And the irony of the situation did not escape some commentators who asked why the outcome should redound to the government's credit when it had been responsible for causing the imbroglio by its ill-advised military actions in the first place and also by its abortive invasion of Angola and repeated violations of that country's territorial integrity. ${ }^{100}$ The SADF magazine, Paratus, adopted a rather more phlegmatic approach to the subject, and welcomed the release of the South African POWs as a breakthrough for improved relations in the region. ${ }^{101}$ But such conciliatory language did not satisfy South Africa's critics, both at home and abroad. As far as the former were concerned, young white conscripts should not be compelled to risk their lives for the sake of the SADF's military adventurism in Angola and its occupation of Namibia. And the latter believed that the SADF should not be allowed to act with impunity against the frontline states and liberation movements with total disregard for the rules of war.

Whilst his fellow SADF soldiers were released and compensated for their privations, ${ }^{102}$ Van der Mescht remained in captivity. But before the exchange was enacted, he had his first visit by an ICRC delegate when Mr Thierry Germond was 
granted an interview at Sao Paulo jail on the night of 1-2 September 1978. The Angolan authorities would not agree to a private meeting and so the interview was conducted in the presence of prison and FAPLA officers. The ICRC delegate found Van der Mescht's responses to his questions rather guarded but the South African did venture to suggest that he deserved better treatment as a POW. Germond reported that Van der Mescht was kept in a small cell with basic amenities comprising running water and a flush toilet. He received three meals per day and was allowed outside three times per week but was confined to a space that was too small for adequate exercise. Van der Mescht complained that he was allowed no contact with the outside world and that he had received neither visits nor mail since his capture. The ICRC representative was able to leave a letter and parcel from the Van der Mescht family with the prison authorities for delivery to the prisoner. Finally, Van der Mescht revealed that he had embarked on a short-lived and unsuccessful hunger strike so as to obtain an interview with a SWAPO representative. He had not had any contact with his captors since his transfer to Sao Paulo although the Namibian liberation movement had presumably approved the ICRC visit. ${ }^{103}$

Although Van der Mescht languished in Sao Paulo prison, his situation improved following his release from solitary confinement. He was befriended by a fellow prisoner and Portuguese national, engineer Cardoso Botelho, who smuggled out a number of his letters. Following the latter's release, these letters were delivered to the South African Embassy in Lisbon by Botelho and his wife. Portuguese Foreign Ministry officials also passed on a letter to the charge d'affaires in the Lisbon Embassy. ${ }^{104}$ In one of these letters addressed to the ambassador (dated 1 December 1979), Van der Mescht bemoaned the conditions under which he was kept, making specific mention of an inadequate diet, a lack of hot water for bathing, and poor health care facilities. He noted "I am supposed to be treated as a POW but I get worse treatment than black criminals in my own country."105 Whilst this statement could be interpreted to mean that Van der Mescht believed that his whiteness should have entitled him to better treatment, it was probably an indication that he was a frightened young man overwhelmed by the situation in which he found himself. Van der Mescht was probably close to a nervous breakdown. After all, SADF members were never briefed as to how they should conduct themselves in the event that they fell into enemy hands. This was simply not something they imagined might happen. Even if Van der Mescht had time to become accustomed to his 
surroundings, he obviously struggled to come to terms with the fate that had befallen him.

Van der Mescht also mentioned that he had only received two letters from home and felt that he had been left to rot in his cell which he called a "stinking rotten rat infested hole". ${ }^{106}$ In his words:

Sometimes I think that my family, government, and even my country I was willing to die for, had deserted me ... I want you to know that I am alive, very low morale, longing for freedom, and all in all completely demoralised...

Van der Mescht signed himself as "a Deserted Soldier". ${ }^{107}$ This was clearly his way of saying that he was disappointed with the lack of urgency that he believed was being attached to securing his release. He was obviously depressed by his lengthy imprisonment and complained about an inability to sleep and nightmares that haunted him. He noted that his experience had changed him; that his family would not recognise him and fathom his behaviour when he eventually returned home.

In a letter addressed to his parents (dated 2 December 1978), Van der Mescht revealed that he was aware of the prisoner swap involving the other POWs and lamented that he was the sole South African remaining in custody. He requested that his parents attempt to send him a transistor radio via the Red Cross representative that visited him periodically so that he might have some contact with the outside world. He also suggested that they attempt to have his letter published in newspapers so that his plight could be brought to the attention of the South African public. This is precisely the action that the government wished to avert as the authorities reckoned that publicity of any kind would be counter-productive to their efforts to employ emissaries to secure Van der Mescht's release. The South African charge d'affaires in Lisbon got wind of the secret and sensitive negotiations being conducted to secure Van der Mescht's release from a colleague in DFA but was not privy to the details. ${ }^{108}$ Whilst he was discouraged from making use of official Portuguese channels such as the office of the Consul General in Luanda to make contact with or smuggle provisions to Van der Mescht, he was told that this did not necessarily rule out using informal contacts such as Botelho. He was informed that it was the government's official position to use the ICRC as an intermediary for fear of jeopardising what little mutual trust had been fostered with the PRA. ${ }^{109}$ 
South Africa continued to cultivate a working relationship with the ICRC in the hope that this might facilitate a breakthrough in negotiating Van der Mescht's release. ICRC delegates visited Van der Mescht twice in 1979 and then again in March 1980. However, on each occasion the ICRC representative was unable to conduct private interviews or inspect the place of detention. ${ }^{110}$

The ICRC faced similar obstacles when it visited the SWAPO and MPLA detainees at Mariental on 3 June 1980. The interviews were conducted with the 118 inmates who were divided into five groups. SADF personnel were not present during these sessions. The ICRC findings were conveyed to members of the SADF at a meeting also attended by the Attorney General of SWA and General Officer Commanding SWA. The ICRC report expressed dissatisfaction with the living conditions, the insufficient personal requisites, inadequate clothing and lack of sports/recreation facilities. It commended the rations as satisfactory although it noted detainees were only given two meals per day. It was impressed with the medical records following the appointment of a full-time medical officer. Yet, it also stated that the authorities should act in the event of (alleged) ill-treatment which might suggest that detainees who lodged complaints were not necessarily believed. The ICRC had no way of knowing that they were not granted access to detainees being subjected to interrogation. It accepted the provision that visitors were not allowed to visit the camp but added that if the detainees were to be considered POWs, then they should be allowed correspondence (subject to censorship). The ICRC attributed the shortcomings to the lack of proper supervision and control by the authorities. ${ }^{111}$ The ICRC's findings reflected the ambiguous status of the detainees who were regarded as terrorists in terms of South African law but then not held by police but confined to a camp run by military personnel. These personnel were not equipped or trained to administer a detention centre. It is not clear whether the SADF had assumed or the SAP had abrogated its responsibilities for the task. Whatever the case, the treatment of the inmates at Mariental followed the model of treatment of political prisoners set by the security forces in South Africa rather than regulations for POWs set out in the Geneva Conventions.

The ICRC published a report of its findings in September 1980. A follow-up visit to Mariental was conducted shortly thereafter. Whilst the SADF had reservations about the negative publicity that the ICRC's reports generated in the international community, it appreciated the value of the organisation's role as intermediary. It also valued its willingness to investigate the whereabouts of missing 
SADF members and arrange for the repatriation of the bodies of those killed in Angola. Accordingly, it was recommended that relations with the ICRC should not be allowed to sour as it would jeopardise the chances of securing the release of POWs in future. The Chief of the SADF expressed the opinion that no course of action that endangered the country's membership of the Geneva Convention should be countenanced. ${ }^{112}$ Whilst the ICRC appeared reluctant to condemn the SADF's treatment of the Mariental detainees, it offered its services to the South African government to assist with the dissemination of knowledge of international humanitarian law among members of the armed forces. ${ }^{113}$ Thus the SADF produced a series of booklets about the Geneva Conventions for its troops. These were simplified expositions of the provisions of the Conventions meant for privates, NCOs and officers, respectively. The SADF also produced a booklet on the treatment of prisoners for the edification of its troops. Although there is anecdotal evidence to suggest that wounded PLAN guerrillas were accorded immediate medical attention and evacuation to medical facilities following fire fights, not all SWAPO captives were treated as POWs. The SADF leadership might have wished to encourage such practices amongst its troops but training did little to cultivate a basic human rights culture at an institutional level. The SADF not only ignored the provisions of the Geneva Conventions pertaining to POWs but condoned many instances in which the human rights of captives were abused. ${ }^{114}$

In January 1981, the Angolan authorities assumed responsibility for safeguarding Van der Mescht but SWAPO still regarded him as their prisoner. SWAPO President, Sam Nujoma, mooted the idea of a prisoner swap involving Van der Mescht, whom he described as "an innocent child and a victim of the war". ${ }^{115} \mathrm{He}$ suggested that Van der Mescht be exchanged for one or other SWAPO member being detained on Robben Island. The proposition was rejected out of hand by South Africa's former Chief of the SADF and now Minister of Defence, Magnus Malan, on the grounds that Namibians on Robben Island were 'common criminals'. 116

On 10 April 1981, delegates from the ICRC paid an unofficial visit to Luanda where they interviewed Van der Mescht in the Sao Paulo prison. Mention was made of the visit of a Russian (probably a KGB agent) who broached the possibility of a prisoner exchange involving the Soviet Union. The South African prisoner raised the possibility of engaging the services of an attorney to handle negotiations for such an exchange. Mr Kelsey Stewart, an attorney from Johannesburg who represented the Press Association and who was President of the 
South African Red Cross was approached by Van der Mescht's wife and agreed to take on the task. In talks with the DFA, the head of the ICRC Mission in South Africa, Nicholas de Rougemont, advised that the South African government rather engage a London-based advocate with experience in matters of handling prisoner exchanges between West and East bloc countries. This was agreed to without abandoning the other channels that were still being used to liaise with SWAPO. ${ }^{117}$ Following prolonged negotiations between National Intelligence Service Director General, Niel Barnard, and the KGB, Van der Mescht and eight high-ranking Western agents serving sentences in the Soviet Union for espionage were exchanged for Soviet spy Major Aleksei Koslov in Berlin on 5 May 1982. ${ }^{118}$

Van der Mescht's release won SWAPO no real concessions from the apartheid regime but it did advance the liberation movement's claim to the moral high ground in terms of international law. This was reflected in an editorial statement in the International Defence Aid Fund's journal Focus which noted that:

The status accorded to Van der Mescht as a prisoner-of-war, and the access given to organisations such as the Red Cross, stands in sharp contrast to South Africa's treatment of captured SWAPO combatants, many of whom simply 'disappear'. 119

Captured SWAPO insurgents were treated as criminals by the South African authorities but in the court of international opinion they were regarded as members of an armed force. This anomaly was made apparent in the trial of three PLAN cadres for sabotage under the Terrorism Act (No. 83 of 1967) in the Windhoek Supreme Court in 1982. ${ }^{120}$ SWAPO called their trial "a blatant violation of the Geneva Conventions, let alone international law relating to South Africa's occupation of Namibia". ${ }^{121}$ Its statement noted that SWAPO held South African prisoners of war according to the provisions of the Geneva Convention and demanded "the immediate and unconditional release of these and all other POWs and political prisoners and detainees". ${ }^{122}$ Professor John Dugard, an expert in international law, testified in mitigation that the 1977 Additional Protocol to the Geneva Conventions specified that members of national liberation movements fighting against colonialism, alien occupation or a racist regime in their right to selfdetermination qualified for POW status. He added that in order to qualify as POWs, the parties had to be involved in a conflict of an international nature and that members of the military wings of liberation movements had to function under a command structure, carry arms openly and wear uniforms or military insignia that 
distinguished combatants from the civilian population. ${ }^{123}$ The evidence before the court confirmed this. Dugard further argued that the case for SWAPO combatants to be regarded as POWs was even stronger than other recognised national liberation movements because of (1) the recognition of the international status of Namibia and hence the international rather than the domestic character of the conflict in the territory; and (2) the categorisation of South Africa's occupation as illegal by the international community. ${ }^{124}$ However, the defence conceded that:

South Africa was not compelled by international law to regard the accused and prisoners in their position as prisoners of war, but that there was sufficient moral and humanitarian considerations why the authorities should accord that status to such prisoners or at least act in the spirit thereof. ${ }^{125}$

Mr Justice Bethune was not persuaded. He ruled that the court was not empowered to declare that 'terrorists' be treated as POWs but was prepared to treat the defendants with some leniency. Accordingly, he sentenced the defendants to lengthy jail terms as he was not inclined to impose the death sentence. ${ }^{126}$ The court was not prepared to question the constitutionality of South African law in Namibia. Nor did it make a ruling on the morality of the justification for the armed struggle for it was bound by legislation which did not allow it the discretion to do so. ${ }^{127}$ In other words, the court deemed that the Namibian war was an internal conflict and that the defendants could not be regarded as POWs as South Africa was not party to the relevant Protocols of the 1977 Geneva Convention. ${ }^{128}$

PLAN guerrillas were regarded as terrorists and were frequently subjected to brutal treatment and torture. Those brought before the courts were prosecuted according to South African laws and sentenced to jail terms (including stints on Robben Island). They were not regarded or treated as POWs. Yet, the SADF insisted that it observed the rules of engagement despite not officially being at war with SWAPO and that the SADF's code of conduct was strictly enforced in the ranks notwithstanding criminal prosecutions preferred against some soldiers for acts such as murder. These charges were withdrawn after the intervention of the Minister of Justice who invoked Article 103 of the Defence Act (which had been extended to Namibia). This provided a loophole for deeds committed 'in good faith' in accordance with the orders of a superior officer. Moreover, a blanket amnesty was extended to South African security forces by the Administrator-General of the territory acting apparently within the framework developed by the UN for the 
transition to independence. These measures were taken to indemnify SADF members from being held liable for illegal acts committed whilst in Namibia. ${ }^{129}$

\section{Conclusion}

The capture of seven SADF troops by the FAPLA/Cuban forces was an unforeseen consequence of Operation Savannah. Another SADF soldier ended up in captivity when he strayed across the Angolan/Namibian border. Before the eight SADF POWs were released, a ninth SADF soldier was captured by SWAPO in Namibia and transferred to an Angolan prison. South Africa expected its captured troops to be treated as POWs, irrespective of whether they were in the uniform of the SADF or not. Even when SADF soldiers masqueraded as mercenaries and were not necessarily entitled to protection in terms of the Geneva Conventions, they were still treated as POWs.

Once South Africa (belatedly) recognised the leverage that POWs provided in negotiating the release of its own soldiers, it became more amenable to according captured Angolan and, especially, Cuban soldiers' treatment in keeping with the terms of the Geneva Conventions. They were recognised as combatants and hence entitled to the protection of LOAC. This was at odds with the treatment meted out to PLAN guerrillas. As we have seen, the apartheid state did not ratify the 1977 Additional Protocol to the Geneva Conventions that accorded 'freedom fighters' the status of combatants subject to certain conditions (outlined above). Thus the South Africans adopted divergent approaches when dealing with SWAPO and the Angolans/Cubans for the release of POWs. This can be attributed to their reasoning that the former were involved in an internal insurrection whereas the latter were members of the military forces of sovereign states - albeit not always treated as such. Whilst they were prepared to deal pragmatically with the Angolan/Cuban governments, they were reluctant to grant the Namibian national liberation movement any form of recognition that would accord SWAPO's armed struggle legitimacy. South Africa's stance flew in the face of international opinion encapsulated in a series of UN resolutions on Namibia, as well as setting it at odds with human rights law exemplified by the Geneva Conventions. 


\section{End notes}

${ }^{1}$ An exception is the case of Major Wynand du Toit, who was captured in 1985 following an abortive mission to sabotage oil installations in the Cabinda enclave. A journalistic account of Du Toit's experiences as a POW sought to capitalise on the publicity that accompanied his release in September 1987. See Soule, A, Dixon, G \& Richards, R. The Wynand du Toit story. Johannesburg: Hans Strydom, 1987. The publication was sponsored by Military Intelligence. See Neels van Tonder's version of the events in Geldenhuys, J (comp). We were there: Winning the war for Southern Africa. Pretoria: Kraal, 2011, 643-653; cf. Geldenhuys, J. At the front: A general's account of South Africa's Border War. Johannesburg: Jonathan Ball, 2009, 222-223. See also Shubin, V. The hot "Cold War": The USSR in Southern Africa. Scottsville: University of KwaZulu-Natal Press, 2008, 102; Steenkamp, W. South Africa's Border War 1966-1989. Gibraltar: Ashanti, 1989, 129-131. Du Toit's story is outside the scope of this article. So, too, is that of Johan Papenfus, who was captured in 1988. This is simply because I have confined this study to the period 1975-1982.

${ }^{2}$ Du Toit Spies, FJ \& Du Preez, S. Operasie Savannah: Angola 1975-76. Pretoria: SA Weermag, Direktoraat Openbare Betrekkings, 1989, 214, 243; Steenkamp op. cit., p. 55; Gleijeses, P. Conflicting missions: Havana, Washington, Pretoria. Alberton: Galago, 2003, 322-323.

${ }^{3}$ Grensoorlog. dir. De Jager, L. Episode 8: '76: Einde van die begin', 2008.

${ }^{4}$ Hallett, R. 'The South African intervention in Angola 1975-76'. African Affairs 77/308. July 1978. 347-386; Addison, G. 'Censorship of the press in South Africa during the Angolan War: A case study of news manipulation and suppression'. MA thesis. Rhodes University, 1980.

${ }^{5}$ The files are located in Minister of Defence (hereafter MV), Gp. 4 Box 138, Ref. 62/14 Krygsgevangenes, 17 December 1975 - 11 May 1977, MV Gp. 5 Box 73, Ref. 62/14 Krygsgevangenes, 11 May 1977 - 16 July 1982, and Chief of Staff Intelligence (hereafter HSI), Gp. 10 Box 1, Ref. MI/106/23 Krygsgevangenes, 6 March 1978 - 20 August 1981.

${ }^{6}$ Captured. dir. Gavshon, I \& Jooste, R. Angel Films, c. 2008.

${ }^{7}$ Captor and captive. dir. Jooste, R \& Bothma, L. Full Circle Productions, 2011.

${ }^{8}$ Lamprecht, D. 'Ek was 'n pyn in die gat vir my regering', Rapport. 1 October 2011. <http://www.rapport.co.za/Weekliks/Nuus/Ek-was-n-pyn-in-die-gatvir-my-regering-20110930\#> Accessed on 6 October 2011.

${ }^{9}$ International Committee of the Red Cross (hereafter ICRC). Basic rules of the Geneva Conventions and their additional protocols. Geneva: ICRC, 1983; Mofidi, M \& Eckert, AE. "'Unlawful combatants" or "prisoners of war": The law and the politics of labels'. Cornell International Law Journal. 36. 2003. 59-92. 
10 Thornberry, C. A nation is born: The inside story of Namibia's independence. Windhoek: Gamsberg Macmillan, 2004, 76, citing Nicholas de Rougemont, erstwhile head of the ICRC Mission in South Africa.

11 Booysen, H. 'Terrorists, prisoners of war, and South Africa'. South African Yearbook of International Law. 1. 1975. 14-45.

12 The SWAPO position is set forth in International Defence and Aid Fund for Southern Africa (hereafter IDAF), Research, Information and Publication Department. Prisoners of war in Namibia: The capture and treatment of combatants of the People's Liberation Army of Namibia (PLAN) and other prisoners-of-war, RI/COMII/002E. No. 10. See Dale, R. 'Delayed decolonization: The diplomatic, economic, and military battlegrounds of the Namibian War of Independence'. Unpublished manuscript, 2011, $218 \mathrm{n}$. 146.

${ }^{13}$ United Nations General Assembly Resolution 3111 (XXVIII), 12 December 1973 cited in McDougall, G 'International Law, Human Rights and Namibian Independence', Human Rights Quarterly 8/3, August 1986, 443.

${ }^{14}$ Saunders, C. 'The South Africa-Angola talks: A little-known Cold War thread'. Paper presented to the Conference on Southern Africa in the Cold War, Lisbon, May 2009.

15 The documentary records of the ICRC dated after 1965 are not yet open to public access. The printed annual and monthly reports are of a perfunctory nature.

${ }^{16}$ Sanders, J. Apartheid's friends: The rise and fall of South Africa's Secret Service. London: John Murray, 2006, 145-165; O'Brien, K. The South African Intelligence Services: From apartheid to democracy, 1948-2005. Abingdon: Routledge, 2011.

${ }^{17}$ Hamann, H. Days of the generals: The untold story of South Africa's apartheidera military generals. Cape Town: Zebra Press, 2001, 26-27; Papenfus, T. Pik Botha and his times. Pretoria: Litera, 2010, 490-491.

18 Westad, OA. 'Moscow and the Angolan Crisis, 1974-76: A new pattern of intervention'. Cold War International History Project Bulletin, 8-9. Winter 1996-1997. 25. Cf. Gleijeses op. cit., p. 352, who contends that the invasion triggered the dispatch of Cuban troops to Angola.

${ }^{19}$ Some commentators (mistakenly) believed that national servicemen could not be deployed outside the country, but Section 1 of the 1957 Defence Act made provision for "military operations in time of war or in connection with the discharge of the obligations of the Republic arising from agreement or for the prevention or suppression of any armed conflict outside the Republic which, in the opinion of the State President, is or may be a threat to the security of the Republic". See Satchwell, K. 'The power to defend: An analysis of various aspects of the Defence Act'. In Cock, J \& Nathan, L (eds), War and society: The militarisation of South Africa, Claremont: David Philip, 1989, 40. 
${ }^{20}$ Sources put the figure of South Africans killed at anywhere between 33 and 49 . See, for example, George, E. The Cuban intervention in Angola, 1965-1991: From Che Guevara to Cuito Cuanavale. London: Frank Cass, 2005, 300; Hamann op. cit., p. 44 and the Wikipedia entry on Operation Savannah, http://en.wikipedia.org/wiki/Operation_Savannah_(Angola).

${ }^{21}$ John, N. 'South African intervention in the Angolan Civil War, 1975-1976: Motivations and implications'. MA thesis. University of Cape Town, 2002, 19.

${ }^{22}$ HIS, MI/106/23, Communication re: 'Omstandighede waarin eie en ander troepe krygsgevange geneem is' from Military Intelligence Division (hereafter MID) to the Secretary, Bureau of State Security, 8 August 1978.

${ }^{23} \mathrm{Du}$ Preez, S. Avontuur in Angola: Die verhaal van Suid-Afrika se soldate in Angola, 1975-76. Pretoria: Van Schaik, 1989, 170.

${ }^{24}$ HSI/11/3/14 Op Savannah, V. 6, Telegram from RSAAMD005 to RSVAM, 15 December 1975.

${ }^{25}$ MV 4/138, Transcript of interview by MID, 17 December 1975.

${ }^{26}$ Addison op. cit., p. 217.

${ }^{27}$ The comment appeared on 20 December 1975. Cited in Gleijeses op. cit., pp. 323-324.

28 The South African Democracy Education Trust (SADET). The road to democracy, V. 2 1970-1980. Pretoria: Unisa Press, 2006, 55.

${ }^{29}$ HSI/11/3/14 Op Savannah, V. 4, Telegram from IMA to Chief of the SADF, 25 November 1975; MI/106/23 op. cit.

${ }^{30}$ A South African propaganda film made about the 'Battle of Bridge 14' (Brug 14) notes that about 30 Cubans had been captured. If this was the case, the majority were presumably turned over to Unita.

${ }^{31}$ George op. cit., p. 112; Bridgland, F. Savimbi: Key to Africa. Sevenoaks: Coronet Books, 1988, 191-192. Gleijeses' claim in Conflicting missions, p. 326 that the story was disinformation designed to undermine Cuban morale is contradicted by the evidence in DoD files detailed below.

${ }^{32}$ HSI, Group 5, Box Ref. 428 2/26/18 Ops Savannah Sekerheidsvoorligting, Memo by Admiral H. Bierman, 'Beleid: Hantering van krygsgevangenes', 28 January 1976. However, the memo stated that Swapo were to be regarded as 'criminals' and 'traitors'.

${ }^{33}$ MV 4/138, Telex, 8 January 1976; MI/106/23 op. cit..

${ }^{34}$ Bridgland op. cit., p. 205.

35 'SA men flown to Khartoum', Rand Daily Mail. 14 January 1976. From Addis Ababa they were flown to Khartoum, where once again they were held up as exemplars of 'South African aggression' by their MPLA escorts.

${ }^{36}$ Addison op. cit., p. 220.

${ }^{37}$ Ibid., p. 242 n. 103; John op. cit., p. 93 n. 235.

${ }^{38}$ John op. cit., p. 72. 
${ }^{39}$ HS1 1/3/14, Op Savannah, V. 9, Confidential letter from the Chief of the SADF, Admiral H Bierman to Heads of Staff personnel, Army and Airforce re Captured SADF Members, 14 January 1976.

${ }^{40}$ ICRC Annual Report 1976. Geneva: ICRC, 1977, 16.

${ }^{41}$ ICRC Statement Des Operations, Zone Afrique, 23 March 1977. Annexe E to letter from Fred Tothill, Representative, South African Permanent Mission, Geneva, to the Secretary for Foreign Affairs, 5 April 1977.

${ }^{42}$ Addison op. cit., p. 220.

${ }^{43}$ George op. cit., p. 303.

${ }^{44}$ Addison op. cit., p. 222; John op. cit., p. 32 n. 129.

${ }^{45}$ ICRC reports dated 20 February, 7 May and 27 November 1976.

${ }^{46}$ The Daily News, 14 December 1976. MV 4/138, Annexure A, Text of news item which appeared heading: 'Datelined Johannesburg Tuesday'.

47 'The strange case of unbelieving Cuban POWs who read the Bible'. Paratus. 28 January 1977. 4-5; John op. cit., p. 32 n. 129.

48 'Happy Cuban prisoners-of-war invite kin to visit South Africa'. Montreal Gazette. 27 September 1976, p. 7.

${ }^{49}$ Gleijeses op. cit., p. 380.

${ }^{50}$ MV 4/138, Annexe to letter from Fred Tothill, Representative, South African Permanent Mission, Geneva, to the Secretary for Foreign Affairs, 5 April 1977.

${ }^{51}$ Ibid.

${ }^{52}$ Ibid.

${ }^{53}$ MV 59/7, MoD directives to Press Council, 9 February 1976 and 21 April 1976.

${ }^{54}$ MV 59/7, Note from MoD to editors, news editors and military correspondents, 6 October 1976.

${ }_{55}^{55}$ Addison op. cit., p. 65; John op. cit., p. 93.

${ }^{56}$ MV 59/7, Minutes of NPU/Defence Committee, 7 August 1976; Addison op. cit., pp. 163-167.

${ }^{57}$ HSI MI/106/23 op. cit.

${ }^{58}$ MV 4/138, HSAW/91/39/1, Notes of a meeting between the Minister of Defence and next-of-kin of South African POWs held in Angola, Pretoria, 4 November 1976.

${ }^{59}$ MV 4/138, MV/MS/62/14, Notes of a meeting between the Minister of Defence and next-of-kin of South African POWs held in Pretoria, 18 November 1976.

${ }^{60}$ MV 4/138, Annexure A, Text of news item which appeared in The Daily News on 14 December 1976 under heading: 'Datelined Johannesburg Tuesday'.

${ }^{61}$ ICRC Annual Report 1976, 16.

${ }^{62}$ MV 4/138, Letter from FD Tothill, SA Permanent Representative, Geneva, to the ${ }^{63}$ Ibid. Secretary of Foreign Affairs, Pretoria, 5 April 1977. 
${ }^{64}$ ICRC Annual Report 1976, 16; ICRC Annual Report 1977, 18.

${ }^{65} \mathrm{MV}$ 4/138, Joint letter from the Kitshoffs, Wiehahns and Groenewalds to the MoD, 21 January 1977 and reply by the MoD, 28 January 1977.

${ }^{66} \mathrm{He}$ was identified as Sergeant Jose Perez Alvarez in MI/106/23 op . cit.

${ }^{67}$ MV/56/6/1, Telegram from South African Permanent Representative, New York, to the Secretary of Foreign Affairs, Cape Town, 7 February 1977.

${ }^{68}$ MV 4/138, Letter from South African Ambassador, Washington, to Secretary of External Affairs, 3 February 1977, which cites a communication that conveys the message.

${ }^{69}$ MV 5/73, Memo re: 'Uitruiling: Krygsgevangenes en oorlogskade', 29 April 1977.

${ }^{70}$ MV 4/138, Letter from MoD to MFA, 24 April 1977.

${ }^{71}$ MV 5/73, Communication by Colonel MS Verster, Defence Ministry Secretary to the Director, Press Secretary to the Prime Minister, 26 October 1977.

72 A group of mercenaries under the command of Costas Georgiou (aka 'Colonel Callan') was recruited to fight alongside the FNLA in northern Angola in late 1975. Thirteen were captured by FAPLA/Cuban forces and tried by the MPLA government in June 1976. Four were executed and nine given lengthy jail terms. See George op. cit., pp. 108-110.

${ }^{73}$ Fauvet, P. 'Angola: The rise and fall of Nito Alves'. Review of African Political Economy, 9. May-August 1977. 100; George op. cit., pp. 126-131.

74 MV 5/73, Report re: 'Op Sago: Vermeende bevrydiging van RSA krygsgevangenes' by Lieutenant General HM du Toit, Chief of Staff Intelligence, n.d.

75 The Soviet Union might have done so, too. Neto certainly believed the Soviets were complicit in the attempted coup. But apart from FAPLA's $8^{\text {th }}$ Brigade, the Angolan troops remained loyal to Neto and Cuban solidarity with the MPLA was never in question.

${ }^{76}$ MV 5/73, Minutes of a meeting between the Ministers of Defence and Foreign Affairs with the next of kin of POWs in Angola, 2 June 1977.

${ }^{77}$ MV 4/138, Letter from MoD to MFA, 24 July 1977.

78 'Skandaal oor 7 in Angola onthul'. Die Afrikaner. 30 September 1977.

${ }^{79}$ MV 5/73 op. cit.

80 'Nog geen plan met agt SA soldate in Angola nie'. Die Afrikaner. 21 October 1977. The photograph of the handcuffed POWs (which the NPU had agreed not to use) was published in Die Afrikaner on at least five occasions. A Commission of Inquiry into the Reporting of Security Matters appointed by PW Botha in 1979 concluded that "[t]he effect of this emotional politically motivated campaign on the [POW's] next-of-kin and other serving soldiers can be imagined". See Report of the Commission of Inquiry into Reporting of Security Matters Regarding the South African Defence Force and the 
South African Police Force, RP 52/1980. Pretoria: Government Printer, 81 Ibid. 1980, 76-77; John op. cit., p. 93.

${ }^{82}$ MV 5/73, Letter from Neville Krige, Director: Press Secretary, Department of the Prime Minister to the Registrar, South African Press Council, 27 October 1977.

${ }^{83}$ MV 5/73, Letter from Neville Krige, Director: Press Secretary, Department of the Prime Minister to the Registrar, South African Press Council, 25 October 1977.

${ }^{84}$ John op. cit., 93.

${ }^{85}$ MV 5/73, Sitrep, 23 February 1978. For Sam Nujoma's self-serving version of Van der Mescht's capture, see Nujoma, S. Where others wavered: The autobiography of Sam Nujoma. London: Panaf, 2001, 316-317.

${ }^{86} \mathrm{MI} / 106 / 23$ op. cit.

${ }^{87}$ MV 4/138, OPS/590, Sitrep 22 February 1978.

88 Williams, C. "'Remember Cassinga?" An exhibition of photographs and histories'. Kronos. 36/1. 2010, 226-227. The interview was screened by BBC TV and other European networks shortly after the SADF assault on Cassinga. See McGill, A. 'The Cassinga raid'. MA thesis. Unisa, 2003, 20.

${ }^{89}$ Sunday Express. 12 March 1978.

${ }^{90}$ MV 4/138, OPS/254, Sitrep 13 March 1978 (my translation).

${ }^{91}$ Deon Lamprecht, 'Ek was ' $\mathrm{n}$ pyn in die gat vir my regering', Rapport , 1 October 2011. Cf. comment by Cheryl van der Mescht that her husband was called a 'traitor' by the mayoress of Brakpan in Captured.

${ }^{92}$ MV 7/73 Annexure to Sitrep 23 February 1978. Statement by Moses Garoeb re 'POWs'.

93 'Prisoners of war'. IDAF Focus. 24. September-October 1979. 14.

${ }^{94}$ MI 106/23 Telegram from US Ambassador to South Africa, Donald McHenry to Minister of Foreign Affairs, RF Botha, 28 June 1978

95 Ibid.

96 The six are listed and named in MI/106/23 op. cit.

${ }^{97}$ MI 106/23 Memo re 'Uitruil van krysgevangenes: RSA/Angola' from General M Malan, Head of the SADF, to HSI, 8 August 1978.

98 ICRC Press Release No. 1336, 4 September 1978; ICRC Annual Report 1978. Geneva: ICRC, 1979, 16; Spies \& Du Toit op. cit., p. 244 n. 9; Gleijeses op. cit., p. 380. The Angolans probably included the six detainees mentioned above.

${ }^{99}$ See, for instance, The Sunday Times of 3 September 1978, of which the front page was headlined: 'Home/Dramatic POW swap'.

${ }^{100}$ The Sunday Times. 3 September 1978; The Rand Daily Mail. 4 September 1978; Addison op. cit., p. 66; John op. cit., p. 93.

101 'POW interlude in Angola'. Paratus. 29 October 1978, p. 10. 
102 The released POWs were allocated the sum of R1 million as compensation for what they endured during captivity by the South African government. This took the form of coupons for consumer goods paid for by money drawn from a secret fund called Project Vampire. See MV 5/73, Letter from Chief of the SADF to the MoD, 22 September 1978.

${ }^{103}$ MV 5/73, ICRC report on a visit to a South African prisoner of war detained in the Sao Paulo Prison in Luanda, 1-2 September 1978.

${ }^{104}$ Wolvaardt, P. A diplomat's story: Apartheid and beyond, 1969-1998. Alberton: Galago, 2005, 75.

${ }^{105}$ Letter from the author's private collection.

106 Ibid.

107 Ibid.

${ }^{108}$ Wolvaardt op. cit., p. 76.

109 Communique re 'Gevangene in Angola: JG van der Mescht' from EA Broekhuysen, Department of Foreign Affairs and Information, to PJ Wolvaardt, SA Embassy, Lisbon, 4 December 1980.

${ }^{110}$ ICRC Annual Report 1979, 19.

$111 \mathrm{MV} / \mathrm{M} 8 / 62 / 14 \mathrm{Memo}$ re 'ICRC visit to detainees at Mariental' from CSP to Chief of the SADF, 12 June 1980.

112 MV/M8/62/14 Letter re 'Besoek deur die IKRK aan Suid-Afrikaanse gevangenisse' from Major General RF Holtzhausen on behalf of the Chief of the SADF to the Commissioner of Prisoners, 12 December 1980.

113 ICRC Annual Report 1980. Geneva: ICRC, 1981, 13; MI 106/23 Memo re 'Besoek aan HSP deur 'n lid van die IKRK: April 1981', Major General AP Roux to MID, 20 May 1981.

${ }^{114}$ See Truth and Reconciliation of South Africa Report. Cape Town: Juta, 19982003, vol. 2 Ch. 2 and vol. 4 Ch. 8, which catalogues some of the gross human rights violations committed by the South African security forces between 1960 and 1990. The record and reputation of Koevoet was far worse than that of the SADF in Namibia.

${ }^{15}$ IDAF Focus. 36. May-June 1981. 3.

${ }^{116}$ Ibid.

${ }^{117}$ MI 106/23 op. cit.

${ }^{118}$ ICRC Annual Report 1982. Geneva: ICRC, 1983, 15; Sanders op. cit., 163. Saunders op. cit., 10 locates Berlin as the site of the exchange and Wolvaardt $o p$. cit., 76 adds that Van der Mescht was flown from Frankfurt to Waterkloof Air Force Base.

${ }^{119}$ IDAF Focus. 42. September-October 1982. 11.

120 The State vs Sagarius, Jason and Malambo. See O'Linn, B. Namibia: Sacred trust of civilization. Windhoek: Gamsberg Macmillan, 2002, 216-221.

${ }^{121}$ ICSA Bulletin. April 1982, cited in SWAPO Information \& Comments, 4/2. February-May 1982. 
122 Ibid.

123 'Prof urges POW status for Swapo'. Rand Daily Mail. 14 May 1982.

${ }^{124}$ IDAF Focus. 41. July-August 1982. 4.

${ }^{125}$ O'Linn op. cit., p. 220.

126 'Swapo insurgents jailed in Windhoek'. Rand Daily Mail. 3 June 1982. The defendants received between nine and eleven years each. The minimum sentence in terms of the Terrorism Act was five years and the maximum was the death sentence.

${ }^{127}$ O'Linn op. cit., p. 220.

${ }^{128}$ Booysen, H. 'Prisoner of War status for South African Citizens or Persons Owing Allegiance to the State'., US Strategic Institute, Strategic Review, 10 (May 1988). 102.

${ }^{129}$ Satchwell op. cit., pp. 41, 49-50; Dale op. cit., pp. 278-279. 